\title{
Frequency of small supernumerary marker chromosomes in prenatal, newborn, developmentally retarded and infertility diagnostics
}

\author{
THOMAS LIEHR and ANJA WEISE \\ Institute of Human Genetics and Anthropology, Kollegiengasse 10, D-07743 Jena, Germany
}

Received December 6, 2006; Accepted January 24, 2007

\begin{abstract}
In this study the substantial and in part contradictory data available in the literature was collected concerning the frequency of small supernumerary marker chromosomes (sSMC) in the human population in general, and in special subpopulations. One hundred and thirty-two studies on sSMC were reviewed. In summary 1,288,693 cytogenetically studied cases detecting 980 sSMC were compiled. In 132 international surveys there were no ethnic effects detected in the sSMC frequency. sSMC were present in $0.075 \%$ of unselected prenatal cases but only in $0.044 \%$ of consecutively studied postnatal ones. In infertile subjects, $0.125 \%$ were sSMC carriers, distinguishing male from female subjects by a 7.5:1 difference in sSMC frequency for this special group. In developmentally retarded patients the sSMC rate was elevated to $0.288 \%$, similar to prenatal cases with ultrasound abnormalities $(0.204 \%)$. No increased risk for the presence of sSMC was detected in ICSI-induced pregnancies. Worldwide there are $\sim 2.7 \times 10^{6}$ living sSMC carriers; $1.8 \times 10^{6}$ have a de novo $\mathrm{sSMC}$ and $\sim 70 \%$ of those are clinically normal. Strikingly, 30-50\% of pregnancies diagnosed with an sSMC fetus are terminated. This may be connected with the empirical risk that $\sim 30 \%$ of sSMC carriers manifest clinical abnormalities. Thus, in summary there is a strong need for a better genotype-phenotype correlation enabling better genetic counseling.
\end{abstract}

\section{Introduction}

Small supernumerary marker chromosomes (sSMC) were recently defined as structurally abnormal chromosomes that cannot be identified or characterized unambiguously by conventional banding cytogenetics alone; they are generally equal in size or smaller than a chromosome 20 of the same metaphase spread. If detected in banding cytogenetics they

Correspondence to: Dr Thomas Liehr, Institut für Humangenetik und Anthropologie, Postfach, D-07740 Jena, Germany

E-mail: i8lith@mti.uni-jena.de

Key words: supernumerary marker chromosomes, developmentally retarded, infertility are still a major problem as they are too small to be considered for their chromosomal origin by traditional banding techniques; molecular cytogenetic techniques are needed for their characterization (1). The risk for an abnormal phenotype in prenatally ascertained de novo cases with sSMC is given as $\sim 13 \%$ (2). This has been refined to $7 \%$ (for sSMC from chromosome $13,14,21$ or 22 ) and $28 \%$ (for all non-acrocentric autosomes) (3) and recently has been suggested to be $26 \%$ (4). Thus, the statement of Paoloni-Giacobino et al (5) is still valid, i.e. cases with a de novo sSMC, particularly prenatally ascertained ones, are not easily correlated with a clinical outcome, even though first approaches in that direction were recently attempted (6). With respect to current technical developments in molecular cytogenetics, such as cenM-FISH techniques (7-9) and molecular genetic approaches as array$\mathrm{CGH},(10)$, further progress in this clinically important field is expected.

However, an important, but not yet thoroughly discussed and understood basic issue is the frequency of sSMC in prenatal as well as in postnatal cases and in patients with infertility or with developmental and/or mental retardation. Here we address this question by reviewing 132 suited datasets derived from the literature as well as from our own laboratory.

\section{Materials and methods}

We recently collected all the literature on SSMC and made it available on the sSMC homepage (11). Based on this collection we presented the available literature from which conclusions on sSMC frequency in different human subpopulations can be drawn. Data from 132 studies with a total of 1,288,693 cytogenetically studied cases detecting 980 sSMC were assembled (Tables I-IV).

According to the cytogenetic definition of an sSMC (1) also cases $\mathrm{i}(18 \mathrm{p}), \operatorname{der}(22), \mathrm{i}(12 \mathrm{p})$ and inv dup(22) were counted as sSMC, if listed separately in any of the 132 included studies.

In summary, 1,074,421 prenatal cases were included in Tables IA and B. In Table IA only unselected prenatal cases $(688,030)$ and in Table IB three types of pre-selected cases were incorporated, i.e. 386,391 cases reporting only de novo aberrations, 4,409 cases selected due to ultrasound abnormalities and 4,625 cases born after ICSI treatment.

In Table IIA, 121,694 consecutive newborn individuals from 10 studies were summarized. Table IIB shows the only available study on 1,405 unselected normal adult cases. 
Table I. sSMC frequency in prenatal cases.

A, Consecutively collected prenatal cases. ${ }^{a}$

\begin{tabular}{|c|c|c|c|c|c|c|}
\hline \multirow{2}{*}{$\begin{array}{l}\text { No. of } \\
\text { study }\end{array}$} & \multirow[t]{2}{*}{ Reference } & \multirow{2}{*}{$\begin{array}{l}\text { Country study } \\
\text { performed in }\end{array}$} & \multirow{2}{*}{$\begin{array}{l}\text { No. of centers } \\
\text { involved }\end{array}$} & \multirow{2}{*}{$\begin{array}{l}\text { Studied } \\
\text { cases }\end{array}$} & \multicolumn{2}{|c|}{ Cases with sSMC } \\
\hline & & & & & Absolute & $(\%)$ \\
\hline 1 & Jotterand-Bellomo et al, 1988 (32) & Switzerland & 1 & 551 & 0 & 0.000 \\
\hline 2 & Fortuny et al, 1988 (33) & Spain & 1 & 600 & 0 & 0.000 \\
\hline 3 & Crandall et al, 1980 (34) & USA & 1 & 2,500 & 0 & 0.000 \\
\hline 4 & Hsieh et al, 1992 (35) & P.R. China & 1 & 2,975 & 0 & 0.000 \\
\hline 5 & Boue et al, 1982 (36) & France & 1 & 5,315 & 0 & 0.000 \\
\hline 6 & Yaegashi et al, 1998 (37) & Japan & 4 & 5,484 & 0 & 0.000 \\
\hline 7 & Eydoux et al, 1989 (13) & France & 4 & 6,515 & 0 & 0.000 \\
\hline 8 & Park et al, 2003 (38) & Korea & 1 & 5,501 & 2 & 0.036 \\
\hline 9 & Caron et al, 1999 (15) & Canada & 1 & 35,131 & 13 & 0.037 \\
\hline 10 & $\begin{array}{l}\text { Stengel-Rutkowski and Nummermann, } \\
1991 \text { (39) }\end{array}$ & Germany & 1 & 7,124 & 3 & 0.042 \\
\hline 11 & Tabor and Philip, 1987 (40) & Denmark & 1 & 2,264 & 1 & 0.044 \\
\hline 12 & Shaffer et al, 2004 (31) & USA & 2 & 45,000 & 22 & 0.048 \\
\hline 13 & Squire et al, 1982 (41) & UK & 1 & 1,687 & 1 & 0.049 \\
\hline 14 & Vejerslev and Mikkelsen, 1989 (42) & $\begin{array}{l}\text { Europe } \\
\text { (14 countries) }\end{array}$ & 36 & 7,800 & 4 & 0.051 \\
\hline 15 & $\begin{array}{l}\text { Association of Clinical Cytogeneticists, } \\
1994 \text { (43) }\end{array}$ & UK & n.a. $(>1)$ & 7,415 & 4 & 0.054 \\
\hline 16 & Stengel-Rutkowski et al, 1978 (44) & Germany & n.a. $(>1)$ & 5,165 & 3 & 0.058 \\
\hline 17 & Thein et al, 2000 (45) & UK & 1 & 1,687 & 1 & 0.059 \\
\hline 18 & Ferguson-Smith and Yates, 1984 (21) & UK & 58 & 52,965 & 32 & 0.060 \\
\hline 19 & Djalali, 1990 (46) & Germany & 1 & 20,370 & 13 & 0.064 \\
\hline 20 & Hsu et al, 1996 (20) & USA & 12 & 179,663 & 113 & 0.063 \\
\hline 21 & Woo et al, 2003 (47) & Korea & 1 & 1,541 & 10 & 0.065 \\
\hline 22 & Daniel et al, 1982 (48) & Australia & 1 & 3,000 & 2 & 0.067 \\
\hline 23 & Grati et al, 2006 (49) & Italy & 85 & 15,109 & 11 & 0.073 \\
\hline 24 & Golbus et al, 1979 (50) & USA & 1 & 2,699 & 2 & 0.074 \\
\hline 25 & Al-Kouatly et al, 2002 (51) & USA & 3 & 9,199 & 7 & 0.076 \\
\hline 26 & Ledbetter et al, 1992 (52) & USA & 9 & 11,436 & 9 & 0.078 \\
\hline 27 & Hook and Cross, 1987 (16) & USA & 40 & 78,567 & 62 & 0.079 \\
\hline 28 & Blennow et al, 1994 (28) & Sweden & 5 & 39,105 & 31 & 0.079 \\
\hline 29 & Bartsch et al, 2005 (53) & Germany & 1 & 43,273 & 42 & 0.097 \\
\hline 30 & Brondum-Nielsen and Mikkelsen M, 1995 (19) & Denmark & 1 & 12,699 & 14 & 0.110 \\
\hline 31 & Li et al, 2000 (54) & USA & 1 & 15,781 & 18 & 0.114 \\
\hline 32 & Benn and Hsu, 1984 (55) & USA & 1 & 6,500 & 8 & 0.123 \\
\hline 33 & Karaman et al, 2006 (27) & Turkey & 2 & 15,792 & 20 & 0.127 \\
\hline 34 & Sachs et al, 1987 (18) & The Netherlands & 1 & 10,000 & 15 & 0.150 \\
\hline 35 & Hume et al, 1995 (26) & USA & 1 & 12,454 & 19 & 0.153 \\
\hline 36 & Kaluzewski et al, 2001 (56) & USA & 1 & 5,955 & 10 & 0.168 \\
\hline 37 & Lippman et al, 1992 (57) & Canada & 7 & 2,888 & 5 & 0.173 \\
\hline 38 & Carrasco Juan et al, 1990 (58) & Spain & 1 & 1,000 & 2 & 0.200 \\
\hline 39 & Authors' laboratory 2000-2005 & Germany & 1 & 2,671 & 6 & 0.225 \\
\hline 40 & $\begin{array}{l}\text { Dahoun-Hadorn and Delozier-Blanchet, } \\
1990 \text { (59) }\end{array}$ & Switzerland & 1 & 811 & 2 & 0.247 \\
\hline 41 & Van den Berg et al, 2000 (60) & The Netherlands & 1 & 1,838 & 7 & 0.381 \\
\hline Sum & & & $\sim 240$ & 688,030 & 514 & 0.075 \\
\hline
\end{tabular}

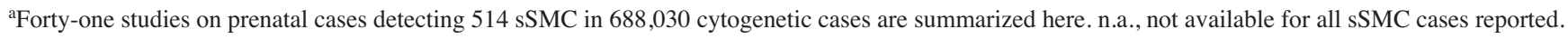


Table I. Continued.

B, Pre-selected prenatal cases. ${ }^{\mathrm{b}}$

\begin{tabular}{|c|c|c|c|c|c|}
\hline \multirow{2}{*}{$\begin{array}{l}\text { No. of } \\
\text { study }\end{array}$} & \multirow[t]{2}{*}{ Reference } & \multirow{2}{*}{$\begin{array}{l}\text { Country study } \\
\text { performed in }\end{array}$} & \multirow{2}{*}{$\begin{array}{l}\text { No. of centers } \\
\text { involved }\end{array}$} & \multirow{2}{*}{$\begin{array}{l}\text { Studied } \\
\text { cases }\end{array}$} & Cases with sSMC \\
\hline & & & & & Absolute $(\%)$ \\
\hline
\end{tabular}

\section{Only de novo sSMC \\ $42 \quad$ Warburton, 1991 (2)}

Only in ultrasound aberrant cases

$\begin{array}{rll}43 & \text { Wilson } \text { et al, } 1992(61) & \text { Canada } \\ 44 & \text { Palmer } \text { et al, } 1992(62) & \text { USA } \\ 45 & \text { Van Zalen-Sprock } \text { et al, } 1991(63) & \text { The Netherlands } \\ 46 & \text { Staebler } \text { et al, } 2005(64) & \text { Belgium } \\ 47 & \text { Daniel } \text { et al, } 2003(65) & \text { Australia } \\ 48 & \text { Rizzo } \text { et al, } 1990(66) & \text { Italy } \\ 7 & \text { Eydoux } \text { et al, } 1989(13) & \text { France } \\ 49 & \text { Hentemann } \text { et al, } 1989(67) & \text { Canada } \\ \text { Sum } & & \end{array}$

\section{ICSI cases}

$\begin{array}{ll}50 & \text { Lam } \text { et al, } 2001(68) \\ 51 & \text { Van Golde } \text { et al, } 1999(69) \\ 52 & \text { Causio } \text { et al, } 1999(70) \\ 53 & \text { Van Opstal } \text { et al, } 1997(71) \\ 54 & \text { Testart } \text { et al, } 1996(72) \\ 55 & \text { Samli } \text { et al, } 2003(73) \\ 56 & \text { Szigeti } \text { et al, } 2004(74) \\ 57 & \text { Wennerholm } \text { et al, 1999 (75) } \\ 58 & \text { Loft } \text { et al, 1999 (76) } \\ 59 & \text { Jozwiak } \text { et al, } 2004(77) \\ 60 & \text { Bonduelle } \text { et al, 2002 (78) } \\ 61 & \text { Wisanto } \text { et al, 1996 (79) } \\ 62 & \text { Aboulghar } \text { et al, 2001 (80) }\end{array}$

Sum

\section{USA, Canada}

\section{2}

377,357

162

0.043

Canada
Spain
Italy
The Netherlands
France
Turkey
Hungary
Sweden
Denmark
Turkey
Belgium
Belgium
Egypt

1
1
1
6
8
1
4
1
23

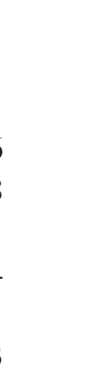

\begin{tabular}{rrrr}
1 & 43 & 0 & 0.000 \\
1 & 56 & 0 & 0.000 \\
1 & 63 & 0 & 0.000 \\
1 & 71 & 0 & 0.000 \\
1 & 108 & 0 & 0.000 \\
1 & 142 & 0 & 0.000 \\
1 & 146 & 0 & 0.000 \\
1 & 149 & 0 & 0.000 \\
13 & 209 & 0 & 0.000 \\
1 & 1,136 & 0 & 0.000 \\
1 & 1,586 & 0 & 0.000 \\
1 & 486 & 1 & 0.205 \\
1 & 430 & 1 & 0.233 \\
25 & 4,625 & 2 & 0.043 \\
\hline
\end{tabular}

b In summary 22 studies on three pre-selected subpopulations of prenatal diagnostics detecting only de novo sSMC or looking for sSMC in ICSI or in ultrasound abnormal prenatal cases. ${ }^{\mathrm{C}}$ Twin pregnancy, both twins had SSMC - familial.

Tables III and IV summarize 69,332 developmentally and/or mentally retarded patients and 30,510 patients with infertility problems, respectively.

In Table $\mathrm{V}$ cases already listed in Table I and II were analyzed for the frequency of de novo and inherited sSMC.

\section{Results}

The goal of this paper was to give an approximate rate of sSMC cases expected in four main groups of patients: prenatal, postnatal, developmentally and/or mentally retarded and infertile people.

Apparent from Tables I-V the study sizes as well as the detection rates of sSMC varied in all reviewed subgroups; between 15 (12) and 377,357 cases (2) and $0(12,13)$ and 162 sSMC carriers (2), respectively. The included cases were studied in time frames between 0.5 (14) and 23 years (15).

Here and in Tables I-V as well as in Figs. 1 and 2 the results for the four aforementioned groups are listed.
Group 1: Prenatal cases. In routine prenatal diagnostics 688,030 cases provided by $>240$ laboratories, including our own detected in summary 514 sSMC (Table IA). The datasets, which were acquired in 20 different countries indicated a frequency of $0.075 \%$ of sSMC in unselected prenatal cases. As summarized in Tables VA and B the detection rate was the same, independent if chorion villi samples (CVS) or amniotic fluid cells (AFC) were studied (Fig. 1). According to study 42 the rate of de novo sSMC was $0.043 \%$; studies 7 and 43-49 indicated an enhanced sSMC rate of $0.204 \%$ in ultrasound-abnormal cases, and in 4.625 ICSI cases (studies 50-62) 2 sSMC were detected (0.043\%) (Table IB).

Group 2: Postnatal cases. In Table IIA we compiled ten newborn studies, to determine the sSMC frequency in the general living human population. Only studies on consecutively newborn children, without further selection criteria were included. In 12,694 postnatal subjects, 54 sSMC cases were described, corresponding to a rate of $0.044 \%$ of 
Table II.

A, Consecutive newborn cases. ${ }^{\mathrm{a}}$

\begin{tabular}{|c|c|c|c|c|c|c|}
\hline \multirow{2}{*}{$\begin{array}{l}\text { No. of } \\
\text { study }\end{array}$} & \multirow[t]{2}{*}{ Reference } & \multirow{2}{*}{$\begin{array}{l}\text { Country study } \\
\text { performed in }\end{array}$} & \multirow{2}{*}{$\begin{array}{l}\text { No. of centers } \\
\text { involved }\end{array}$} & \multirow{2}{*}{$\begin{array}{l}\text { Studied } \\
\text { cases }\end{array}$} & \multicolumn{2}{|c|}{ Cases with sSMC } \\
\hline & & & & & Absolute & $(\%)$ \\
\hline 63 & Lin et al, 1976 (14) & Canada & 1 & 930 & 0 & 0.000 \\
\hline 64 & Xia et al, $1982(81)$ & P.R. China & 1 & 2,079 & 0 & 0.000 \\
\hline 65 & Maeda et al, 1991 (82) & Japan & 1 & 14,835 & 4 & 0.027 \\
\hline 66 & Hook and Hamerton, 1977 (17) & Canada, UK, Denmark, USA & 7 & 56,952 & 16 & 0.028 \\
\hline 67 & Buckton et al, 1985 (83) & UK & 1 & 3,993 & 2 & 0.050 \\
\hline 68 & Nielsen and Rasmussen, 1975 (23) & Denmark & 1 & 11,148 & 6 & 0.054 \\
\hline 69 & Bratkowska et al, 1985 (84) & Poland & 1 & 3,665 & 2 & 0.055 \\
\hline 70 & Nielsen and Wohlert, 1991 (22) & Denmark & 1 & $23,762^{b}$ & 18 & 0.076 \\
\hline 71 & Buchkov et al, 1974 (85) & Russia & 1 & 2,500 & 2 & 0.080 \\
\hline 72 & Hansteen et al, 1982 (86) & Norway & 1 & 1,830 & 4 & 0.219 \\
\hline Sum & & & 16 & 121,694 & 54 & 0.044 \\
\hline
\end{tabular}

${ }^{a}$ Ten studies on consecutive newborn cases detecting in summary 54 sSMC in 121,694 cases. ${ }^{b}$ Without the cases previously mentioned in Nielsen and Rasmussen, 1975

B, Normal adult cases. ${ }^{c}$

\begin{tabular}{|c|c|c|c|c|c|c|}
\hline \multirow{2}{*}{$\begin{array}{l}\text { No. of } \\
\text { study }\end{array}$} & \multirow[t]{2}{*}{ Reference } & \multirow{2}{*}{$\begin{array}{l}\text { Country study } \\
\text { performed in }\end{array}$} & \multirow{2}{*}{$\begin{array}{l}\text { No. of centers } \\
\text { involved }\end{array}$} & \multirow{2}{*}{$\begin{array}{l}\text { Studied } \\
\text { cases }\end{array}$} & \multicolumn{2}{|c|}{ Cases with sSMC } \\
\hline & & & & & Absolute & $(\%)$ \\
\hline 73 & Tawn and Earl, 1992 (87) & UK & 1 & 1,405 & 1 & 0.071 \\
\hline
\end{tabular}

'Only one small study was available on sSMC frequency in normal adult humans.

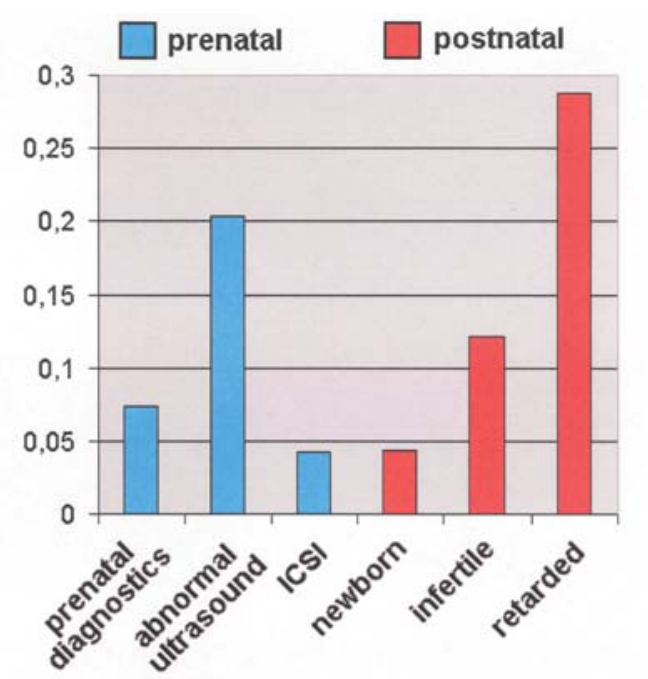

Figure 1. The frequency of sSMC. Data for prenatal (blue columns) and postnatal studies (red columns) according to Tables I-IV is summarized. The sSMC frequencies in prenatal diagnostics (Table IA), in ultrasound abnormal and in ICSI-induced pregnancies (Table IB) are shown in comparison to sSMC frequencies in newborn, infertile and developmentally retarded subjects.

sSMC carriers in the general population. In study $73,1,405$ normal probands were cytogenetically analyzed and $1 \mathrm{sSMC}$ carrier was identified (Table IIB).
Group 3: Developmentally retarded patients. Twenty-six studies provided 69,332 developmentally retarded patients and $200 \mathrm{sSMC}$ carriers were identified, i.e. a rate of $0.288 \%$ (Table III).

Group 4: Patients with fertility problems. Forty-one cytogenetic studies on a total of 30,510 patients with different fertility problems were available. In general a rate of $0.125 \%$ sSMC carriers was detected. When analyzing the dataset of Table IV in a gender-specific manner, the picture changes; i.e. $36 / 21,841(0.165 \%)$ male and 2/9,165 (0.022\%) woman sSMC carriers were found.

In Table VA-C also the rate of de novo and familial sSMC was determined based on the studies listed in Tables IA and IIA. According to the studies in which pertinent data was available, de novo sSMC constituted $\sim 70 \%$ and familial, $\sim 30 \%$ of the cases (Fig. 2).

\section{Discussion}

The frequency of sSMC carriers was given in the literature normally by citing 1-3 more or less randomly selected population studies, most frequently those of Hook and Hamerton (16), Hook and Cross (17), Sachs (18), Warburton (2), Brondum-Nielsen and Mikkelsen (19) and Hsu et al (20). Thus, the sSMC frequency was normally presented as between $0.028 \%$ and $0.150 \%$. 
Table III. Developmentally and/or mentally retarded patients. ${ }^{a}$

\begin{tabular}{|c|c|c|c|c|}
\hline \multirow[t]{2}{*}{ No. of study } & \multirow[t]{2}{*}{ Reference } & \multirow[t]{2}{*}{ Studied cases } & \multicolumn{2}{|c|}{ Cases with sSMC } \\
\hline & & & Absolute & $(\%)$ \\
\hline 74 & Cora et al, $2000(88)$ & 120 & 0 & 0.000 \\
\hline 75 & Kodama, 1982 (89) & 197 & 0 & 0.000 \\
\hline 76 & Srsen et al, 1989 (90) & 324 & 0 & 0.000 \\
\hline 77 & Al Husain and Zaki, 1999 (91) & 337 & 0 & 0.000 \\
\hline 78 & Higurashi et al, 1985 (92) & 455 & 0 & 0.000 \\
\hline 79 & Fryns et al, $1982(93)$ & 32,930 & 62 & 0.118 \\
\hline 80 & Rasmussen et al, 1982 (94) & 1,905 & 3 & 0.158 \\
\hline 81 & Hernández et al, 1990 (95) & 1,586 & 3 & 0.189 \\
\hline 82 & Moreno-Garcia et al, 2005 (96) & 972 & 2 & 0.206 \\
\hline 83 & Wuu et al, $1984(97)$ & 470 & 1 & 0.213 \\
\hline 84 & Phelan et al, 1996 (98) & 4,485 & 11 & 0.245 \\
\hline 85 & Price et al, 1976 (99) & 611 & 2 & 0.327 \\
\hline 67 & Buckton et al, 1985 (83) & 3,673 & 12 & 0.327 \\
\hline 86 & Bourgeois and Benezech, 1977 (100) & 600 & 2 & 0.333 \\
\hline 21 & Woo et al, 2003 (47) & 1,443 & 5 & 0.347 \\
\hline 36 & Kaluzewski et al, 2001 (56) & 902 & 4 & 0.443 \\
\hline 87 & Hou and Wang, 1998 (101) & 11,893 & 54 & 0.454 \\
\hline 88 & Hong et al, 1999 (102) & 604 & 3 & 0.500 \\
\hline 89 & Kim et al, 1999 (103) & 4,117 & 24 & 0.583 \\
\hline 90 & Singh et al, 1974 (104) & 504 & 3 & 0.595 \\
\hline 91 & Kirkilionis and Sergovich, 1987 (105) & 495 & 3 & 0.606 \\
\hline 92 & Toyota et al, 2001 (106) & 161 & 1 & 0.621 \\
\hline 93 & Mulcahy and Jenkyn, 1972 (107) & 154 & 1 & 0.649 \\
\hline 94 & Battaglia et al, 1999 (108) & 120 & 1 & 0.833 \\
\hline 95 & Felix et al, 1998 (109) & 202 & 2 & 0.990 \\
\hline 96 & Borgaonkar et al, 1971 (110) & 72 & 1 & 1.389 \\
\hline Sum & & 69,332 & 200 & 0.288 \\
\hline
\end{tabular}

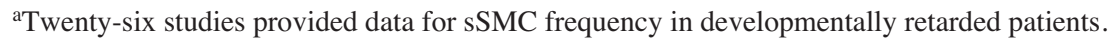

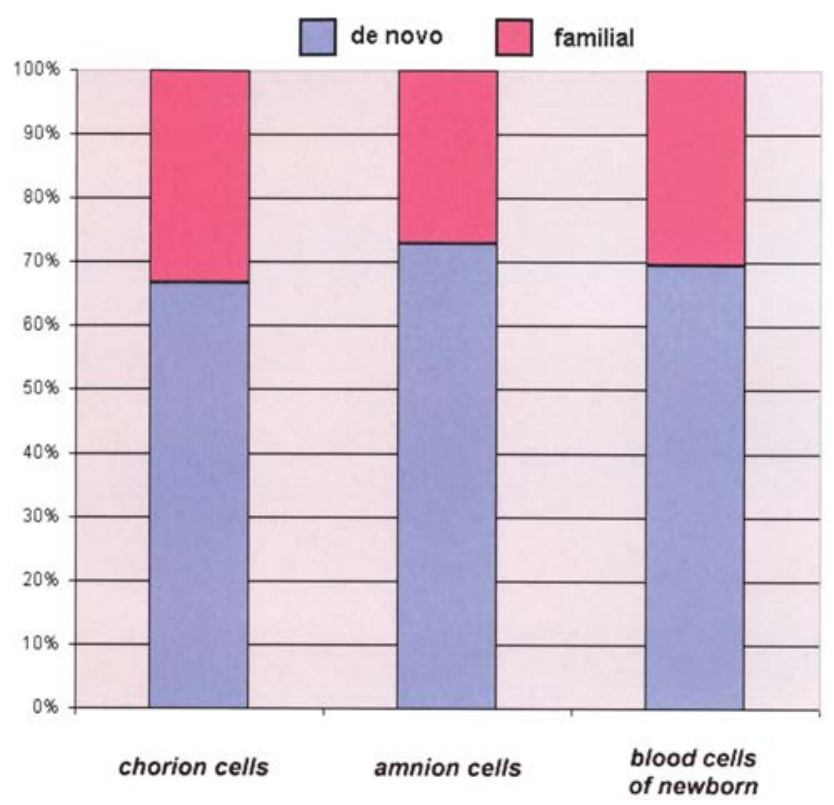

Figure 2. Frequency of de novo and familial sSMC. Comparison of the frequency of de novo and familial sSMC in CVS, AFC and blood of newborn cases based on the data provided in Table $\mathrm{V}$. The rate is more or less always 2:1.
These variations are mainly caused by the studied population size and the bias a single study can be subjected to. The prenatal, as well as the postnatal studies included data worldwide, as detailed in Tables I and II in the category 'Country study performed in'. As countries such as Australia, Canada and the USA included people from Asian, African, Australian and European descent, all ethnic groups were represented in the studies. Moreover, different European, Egyptian, Japanese, Korean and Chinese studies were also included. For example, five studies performed in Germany, a country with a relatively homogeneous population showed variations between $0.042 \%$ and $0.225 \%$ of the detection rate for prenatal sSMC (Table I, studies 10, 16, 19, 29 and 39). An ethnic effect in sSMC frequency was not detected, at least not on the available sample size.

Here we attempted to ascertain the frequency of sSMC carriers in the general population and in some subpopulations.

As some well-recognized and frequently cited previous studies $(2,21)$ summarized data from different laboratories in similar ways to us, the present attempt to compile patient data from 132 studies in 4 different main groups: prenatal, postnatal, developmentally and/or mentally retarded and infertile seemed to be legitimate and straight forward. However, during this review we encountered problems 
Table IV. Patients with fertility problems. ${ }^{\mathrm{a}}$

\begin{tabular}{|c|c|c|c|c|c|c|c|}
\hline \multirow[t]{2}{*}{ No. of study } & \multirow[t]{2}{*}{ Reference } & \multicolumn{3}{|c|}{ Number of studied cases } & \multicolumn{3}{|c|}{ Cases with sSMC } \\
\hline & & Male & Female & Total & Male & Female & Total $(\%)$ \\
\hline 97 & Martin et al, 1986 (12) & 0 & 15 & 15 & n.a. & 0 & 0.000 \\
\hline 51 & Van Golde et al, 1999 (69) & 23 & n.a. & 23 & 0 & n.a. & 0.000 \\
\hline 98 & Baschat et al, 1996 (111) & 32 & n.a. & 32 & 0 & n.a. & 0.000 \\
\hline 99 & Kleiman et al, 1999 (112) & 72 & n.a. & 72 & 0 & n.a. & 0.000 \\
\hline 100 & Penna Videaú et al, 2001 (113) & 84 & n.a. & 84 & 0 & n.a. & 0.000 \\
\hline 101 & Quilter et al, 2003 (114) & 103 & n.a. & 103 & 0 & n.a. & 0.000 \\
\hline 102 & Stuppia et al, 1998 (115) & 126 & n.a. & 126 & 0 & n.a. & 0.000 \\
\hline 103 & Raziel et al, 2002 (116) & 65 & 65 & 130 & 0 & 0 & 0.000 \\
\hline 104 & Westlander et al, 1999 (117) & 137 & n.a. & 137 & 0 & n.a. & 0.000 \\
\hline 105 & Lange et al, 1993 (118) & 72 & 72 & 144 & 0 & 0 & 0.000 \\
\hline 106 & Schreurs et al, 2000 (119) & - & 163 & 163 & n.a. & 0 & 0.000 \\
\hline 107 & Pauer et al, 1997 (120) & 128 & 122 & 250 & 0 & 0 & 0.000 \\
\hline 77 & Al Husain and Zaki, 1999 (91) & 128 & 129 & 257 & 0 & 0 & 0.000 \\
\hline 108 & Farzanfar and Azimi, 2005 (121) & 257 & n.a. & 257 & 0 & n.a. & 0.000 \\
\hline 109 & Crüger et al, 2003 (122) & 392 & n.a. & 392 & 0 & n.a. & 0.000 \\
\hline 110 & Micic et al, 1984 (123) & 820 & n.a. & 820 & 0 & n.a. & 0.000 \\
\hline 111 & Matsuda et al, 1989 (124) & 554 & n.a. & 554 & 0 & n.a. & 0.000 \\
\hline 52 & Causio et al, 1999 (70) & 301 & 301 & 602 & 0 & 0 & 0.000 \\
\hline 112 & Haidl et al, 2000 (125) & 305 & 305 & 610 & 0 & 0 & 0.000 \\
\hline 2 & Fortuny et al, 1988 (33) & 445 & 445 & 890 & 0 & 0 & 0.000 \\
\hline 113 & Yoshida et al, 1997 (126) & 1,007 & n.a. & 1,007 & 0 & n.a. & 0.000 \\
\hline 114 & Makino et al, 1990 (127) & 639 & 639 & 1,278 & 0 & 0 & 0.000 \\
\hline 115 & Celep et al, 2006 (128) & 645 & 645 & 1,290 & 0 & 0 & 0.000 \\
\hline 116 & Palka et al, 1978 (129) & 2,078 & n.a. & 2,078 & 2 & n.a. & 0.048 \\
\hline 117 & Peschka et al, 1999 (130) & 781 & 781 & 1,562 & 1 & 0 & 0.064 \\
\hline 118 & Radojcic Badovinac et al, 2000 (131) & 676 & 624 & 1,300 & 2 & 0 & 0.077 \\
\hline 119 & Gekas et al, 2001 (132) & 2,196 & 1,012 & 3,208 & 3 & 0 & 0.094 \\
\hline 120 & Hens et al, 1988 (133) & 500 & 500 & 1,000 & 1 & 0 & 0.100 \\
\hline 121 & Meschede et al, 1998 (134) & 432 & 436 & 868 & 1 & 0 & 0.115 \\
\hline 122 & Scholtes et al, 1998 (135) & 1,116 & 1,164 & 2,280 & 3 & 0 & 0.132 \\
\hline 123 & Morel et al, 2004 (136) & 335 & 370 & 705 & 1 & 0 & 0.142 \\
\hline 124 & Van Assche et al, 1996 (137) & 694 & n.a. & 694 & 1 & n.a. & 0.144 \\
\hline 54 & Testart et al, 1996 (72) & 261 & 261 & 522 & 1 & 0 & 0.192 \\
\hline 125 & Tuerlings et al, 1998 (138) & 1,792 & n.a. & 1,792 & 4 & n.a. & 0.223 \\
\hline 126 & Chandley et al, 1975 (139) & 1,599 & 966 & 2,565 & 4 & 2 & 0.234 \\
\hline 127 & Pandiyan and Jequier, 1996 (140) & 1,210 & n.a. & 1,210 & 3 & n.a. & 0.248 \\
\hline 128 & Mau et al, 1997 (141) & 150 & 150 & 300 & 1 & n.a. & 0.333 \\
\hline 129 & Bourrouillou et al, 1985 (142) & 952 & n.a. & 952 & 4 & n.a. & 0.420 \\
\hline 130 & Dohle et al, 2002 (143) & 150 & n.a. & 150 & 1 & n.a. & 0.667 \\
\hline 131 & Retief et al, 1984 (144) & 496 & n.a. & 496 & 2 & n.a. & 0.403 \\
\hline 132 & Nagvenkar et al, 2005 (145) & 88 & n.a. & 88 & 1 & 0 & 1.136 \\
\hline Sum & & 21,841 & 9,165 & 30,510 & $\begin{array}{c}36 \\
=0.165 \%\end{array}$ & $\begin{array}{c}2 \\
=0.022 \%\end{array}$ & 0.125 \\
\hline
\end{tabular}

${ }_{\mathrm{S}}^{\mathrm{SSMC}}$ frequency in patients with fertility problems was found to be on average $0.125 \%$, but $0.165 \%$ for male and $0.022 \%$ for female subjects. n.a., not available for all sSMC cases reported.

concerning the comparability of the research papers included. Especially for the prenatally analyzed cases (Table I) some of the reported details were different, e.g. study 42 (2) only reported de novo and no familial sSMC cases. Others such as study 18 of Ferguson-Smith MA and Yates (21) did not discriminate between familial or de novo sSMC; the later study also provided no information whether AFC and CVS were analyzed. Thus, to answer questions concerning frequencies in different tissue types and the parental origin of sSMC, the data summarized in Tables IA and IIA was extracted, and the relevant studies were included in Table VA-C.

Another problem was that datasets of some of the studies included in Tables I-IV were repeatedly published in an 
Table V. Excerpt of Tables I and II concerning the frequency and the parental origin of sSMC in CVS, AFC and blood of newborn cases.

A, Parental origin of sSMC in CVS.

\begin{tabular}{|c|c|c|c|c|c|}
\hline \multirow[t]{2}{*}{ No. of study } & \multirow[t]{2}{*}{ Reference } & \multirow[t]{2}{*}{ Studied cases } & \multirow[t]{2}{*}{ Cases with sSMC } & \multicolumn{2}{|c|}{ Parental origin of sSMC } \\
\hline & & & & De novo & Familial \\
\hline 1 & Jotterand-Bellomo et al, 1988 (32) & 551 & 0 & 0 & 0 \\
\hline 7 & Eydoux et al, 1989 (13) & $4^{\mathrm{a}}$ & 0 & 0 & 0 \\
\hline 10 & Stengel-Rutkowski and Nummermann, 1991 (40) & 7,124 & 3 & n.a. & n.a. \\
\hline 14 & Vejerslev and Mikkelsen, 1989 (42) & 7,800 & 4 & n.a. & n.a. \\
\hline 15 & Association of Clinical Cytogeneticists, 1994 (43) & 7,415 & 4 & n.a. & n.a. \\
\hline 23 & Grati et al, 2006 (49) & 15,109 & 11 & n.a. & n.a. \\
\hline 26 & Ledbetter et al, 1992 (52) & 11,436 & 9 & n.a. & n.a. \\
\hline 28 & Blennow et al, 1994 (28) & $4,159^{\mathrm{a}}$ & 1 & 1 & 0 \\
\hline 30 & Brondum-Nielsen and Mikkelsen M, 1995 (19) & $1,644^{\mathrm{a}}$ & 1 & 1 & 0 \\
\hline 33 & Karaman et al, 2006 (27) & $904^{\mathrm{b}}$ & 0 & 0 & 0 \\
\hline 34 & Sachs et al, 1987 (18) & $1^{\mathrm{a}}$ & 0 & 0 & 1 \\
\hline 37 & Lippman et al, 1992 (57) & $1,019^{\mathrm{a}}$ & 4 & 2 & 2 \\
\hline 39 & Authors' laboratory 2000-2005 & $140^{\mathrm{a}}$ & 0 & 0 & 0 \\
\hline 41 & van den Berg et al, 2000 (60) & 1,838 & $7^{\mathrm{c}}$ & 4 & 1 \\
\hline Sum & & 59,144 & $\begin{aligned} & 44 \\
= & 0.074 \%\end{aligned}$ & $\begin{array}{c}8 / 9,705 \\
=0.082 \%\end{array}$ & $\begin{array}{c}4 / 9,705 \\
=0.041 \%\end{array}$ \\
\hline
\end{tabular}

${ }^{a} \mathrm{AFC}$ cases were excluded; ${ }^{\mathrm{A}} \mathrm{AFC}$ cases and fetal blood cases were excluded; ${ }^{c}$ two cases with unknown parental origin. n.a., not available for all sSMC cases reported.

$\mathrm{B}$, Parental origin of sSMC in AFC.

\begin{tabular}{|c|c|c|c|c|c|}
\hline \multirow[t]{2}{*}{ No. of study } & \multirow[t]{2}{*}{ Reference } & \multirow[t]{2}{*}{ Studied cases } & \multirow[t]{2}{*}{ Cases with sSMC } & \multicolumn{2}{|c|}{ Parental origin of sSMC } \\
\hline & & & & De novo & Familial \\
\hline 2 & Fortuny et al, 1988 (33) & 600 & 0 & 0 & 0 \\
\hline 3 & Crandall et al, 1980 (34) & 2,500 & 0 & 0 & 0 \\
\hline 4 & Hsieh et al, 1992 (35) & 2,975 & 0 & 0 & 0 \\
\hline 5 & Boue et al, 1982 (36) & 5,315 & 0 & 0 & 0 \\
\hline 6 & Yaegashi et al, 1998 (37) & 5,484 & 0 & 0 & 0 \\
\hline 7 & Eydoux et al, 1989 (13) & 6,515 & 0 & 0 & 0 \\
\hline 11 & Tabor and Philip, 1987 (40) & 2,264 & 1 & 0 & 1 \\
\hline 13 & Squire et al, 1982 (41) & 2,036 & 1 & 1 & 0 \\
\hline 16 & Stengel-Rutkowski et al, 1978 (44) & 5,165 & 3 & n.a. & n.a. \\
\hline 18 & Ferguson-Smith and Yates, 1984 (21) & 52,965 & 32 & n.a. & n.a. \\
\hline 19 & Djalali, 1990 (46) & 20,370 & 7 & n.a. & n.a. \\
\hline 20 & Hsu et al, 1996 (20) & 179,663 & 113 & n.a. & n.a. \\
\hline 21 & Woo et al, 2003 (47) & 1,541 & 9 & n.a. & n.a. \\
\hline 22 & Daniel et al, 1982 (48) & 3,000 & 2 & 1 & 1 \\
\hline 24 & Golbus et al, 1979 (50) & 2,699 & 2 & n.a. & n.a. \\
\hline 25 & Al-Kouatly et al, 2002 (51) & $8,642^{\mathrm{d}}$ & 7 & 6 & 1 \\
\hline 27 & Hook and Cross, 1987 (16) & 78,567 & 62 & n.a. & n.a. \\
\hline 28 & Blennow et al, 1994 (28) & $34,908^{\mathrm{d}}$ & 30 & n.a. & n.a. \\
\hline 29 & Bartsch et al, 2005 (53) & 43,273 & 42 & 29 & 13 \\
\hline 30 & Brondum-Nielsen and Mikkelsen M, 1995 (19) & $11,055^{\mathrm{d}}$ & 13 & 8 & 5 \\
\hline 31 & Li et al, 2000 (54) & 15,781 & 18 & n.a. & n.a. \\
\hline 32 & Benn and Hsu, 1984 (55) & 6,500 & 8 & 5 & 3 \\
\hline 33 & Karaman et al, 2006 (27) & $11,898^{\mathrm{e}}$ & 14 & 12 & 2 \\
\hline 34 & Sachs et al, 1987 (18) & $9,999^{\mathrm{d}}$ & 14 & 14 & 0 \\
\hline 37 & Lippman et al, 1992 (57) & $968^{\mathrm{d}}$ & 1 & 1 & 0 \\
\hline 38 & Carrasco Juan et al, 1990 (58) & 1,000 & 2 & 0 & 2 \\
\hline
\end{tabular}


Table VB. Continued.

\begin{tabular}{|c|c|c|c|c|c|}
\hline \multirow[t]{2}{*}{ No. of study } & \multirow[t]{2}{*}{ Reference } & \multirow[t]{2}{*}{ Studied cases } & \multirow[t]{2}{*}{ Cases with sSMC } & \multicolumn{2}{|c|}{ Parental origin of sSMC } \\
\hline & & & & De novo & Familial \\
\hline 39 & own laboratory $2000-2005$ & $2,531^{\mathrm{d}}$ & 6 & 4 & 2 \\
\hline 40 & Dahoun-Hadorn and Delozier-Blanchet, 1990 (59) & 811 & 2 & 1 & 1 \\
\hline Sum & & 519,025 & $\begin{aligned} & 382 \\
= & 0.074 \%\end{aligned}$ & $\begin{array}{l}82 / 122,051 \\
=0.067 \%\end{array}$ & $\begin{array}{r}31 / 122,051 \\
=0.025 \%\end{array}$ \\
\hline
\end{tabular}

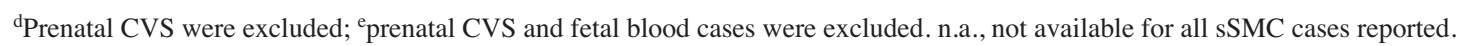

C, Parental origin of sSMC in the blood of newborn cases.

\begin{tabular}{|c|c|c|c|c|c|}
\hline \multirow[t]{2}{*}{ No. of study } & \multirow[t]{2}{*}{ Reference } & \multirow[t]{2}{*}{ Studied cases } & \multirow[t]{2}{*}{ Cases with sSMC } & \multicolumn{2}{|c|}{ Parental origin of sSMC } \\
\hline & & & & De novo & Familial \\
\hline 63 & Aboulghar et al, 2001 (80) & 930 & 0 & 0 & 0 \\
\hline 68 & Nielsen and Rasmussen, 1975 (23) & 11,148 & 6 & 4 & 2 \\
\hline 72 & Hansteen et al, $1982(86)$ & 1,830 & 4 & 3 & 1 \\
\hline Sum & & 13,908 & $\begin{array}{c}10 \\
=0.071 \%\end{array}$ & $\begin{array}{c}7 \\
=0.050 \%\end{array}$ & $\begin{array}{c}3 \\
=0.022 \%\end{array}$ \\
\hline
\end{tabular}

'overlapping' way in several papers, e.g. some data available in Nielsen and Wohlert (22) was previously reported in Nielsen and Rasmussen (23). Thus, one had to be extremely careful not to include the same data twice, especially, as in some publications not very detailed and/or comprehensive references were given on previously published data. To the best of our knowledge we avoided the double use of identical, but repeatedly published data in all Tables.

The last and maybe most critical point concerning the comparability of the studies included in Tables I-IV is that when all these studies were performed, no uniform definition of an sSMC was available. Thus, apart from the study of Warburton (2), it was hard if not impossible to know if an sSMC included or excluded isochromosomes $9 \mathrm{p}, 12 \mathrm{p}, 18 \mathrm{p}$ or Pallister-Killian syndrome and Cat-eye- or der(22)-syndrome chromosomes. While isochromosomes 9p are not sSMC according to the definition of Liehr et al (1), the other ones are. However, this point was not clarified and was also never questioned in the previous studies included in Tables I-IV. The presence of sSMC was only one of many different cytogenetic aberrations listed in these studies, and for each author/ author group there was no question as to what an SSMC was it seemed clear to them and thus required no closer reflection.

According to the data from ten consecutive, completely unselected newborn studies (Table IIA), a rate of $0.044 \%$ of sSMC carriers was determined in the general living newborn population. With an estimated human world population of $6,560,000,000$ people there are at present $\sim 2.7 \times 10^{6}$ living sSMC carriers.

As previously described (1), the sSMC rate is $\sim 7 \mathrm{x}$ higher in (develop)mentally retarded patients (Table III) than in the normal population. This is similar, as we will discuss later, for the prenatal cases with ultrasound abnormalities, not surprising due to the fact that patients with $\mathrm{i}(12 \mathrm{p}), \mathrm{i}(18 \mathrm{p})$, $\mathrm{i}(22)$, der(22) but also larger inv dup(15) are overrepresented in this clinical group.
Patients with fertility problems (Table IV) have a $\sim 2.9 \mathrm{x}$ enhanced risk for an sSMC compared to the general population. To note, the rate of sSMC carriers in males versus females was 7.5:1. This observation was biased by heterogeneous reasons which led to the likely inclusion into the group of 'infertility patients' which were studied cytogenetically. However, the rate of male versus female sSMC carriers is strikingly different; and if valid, the mechanisms why an sSMC leads predominantly to male fertility problems have not been eludidated as yet. However, there are hints that oligozoospermia is significantly correlated with sSMC presence in $7 \%$ of subjects, while in azoospermia patients, sSMC is present in $<1 \%$ of the corresponding cases (24). These observations also fit the recently outlined fact that familial sSMC are predominantly inherited via the maternal line (25).

According to the data reviewed here, sSMC are to be expected in $0.075 \%$ of all analyzed prenatal cases. There was no difference in the sSMC rate in CVS compared to AFC (Table VA and B). Thus, it can be carefully concluded that there seems to be no significant loss of pregnancies in connection with sSMC between weeks 10-14 (analysis of CVS) compared to weeks 9-15 (analysis of AFC).

Information on the parental origin in 9,705 CVS, 12,2051 AFC and 13,908 newborn cases was available (Table V). The rate of familial versus de novo cases is 1:2 in all three groups (Fig. 2). Consequently the rate of familial sSMC cases of $\sim 30 \%$ is significantly lower compared to the previously suggested value of $\sim 40 \%$ (reviewed in ref. 1). This data is also supported by the study of Hume et al (26), which could not be included in Table $\mathrm{V}$ due to the lack of data; they report that out of $19 \mathrm{sSMC}$ cases only 5 were inherited, i.e. $26.3 \%$.

The most cited and extensive prenatal study of Warburton (2) accounting for an sSMC frequency of $0.043 \%$ of de novo cases was based on a pre-selected collection, as i) she 
reported exclusively de novo (sSMC) cases while all other studies did not distinguish de novo and familial sSMC, and ii) she did not include extra chromosomes of identified origin, i.e. all cases with isochromosomes $9 \mathrm{p}$, isochromosomes 18 p, Pallister-Killian-, Cat-eye- and der(22)-syndrome chromosomes. So in summary, she underestimated the sSMC frequency in prenatal diagnostics compared to the other studies due to her inclusion criteria. Thus, her study was listed in Table IB together with the other pre-selected cytogenetic studies in prenatal diagnostics: those with detectable ultrasound abnormalities and those after induction of the pregnancy by ICSI. There was a strong positive correlation of sSMC presence and ultrasound abnormalities (Table IB). With $0.204 \%$ this rate was $\sim 2.7 \mathrm{x}$ higher than in the general prenatal population. As well known syndromes such as Pallister-Killian, Cat-Eye, i(18p) or der(22) were included here, which normally are connected with malformations, this observation was not unexpected. For ICSI-induced pregnancies only 2 sSMC carriers among 4,625 cytogenetically studied newborns were observed. With a rate of $0.043 \%$ this was $1.7 \mathrm{x}$ less frequent than in all of the prenatally studied cases of Table IA. However, with high probability this observation was caused by the 146-fold smaller sample size available for ICSI pregnancies compared to all others (Table IA). In the prenatal study of Karaman et al (27) (study 33 in Table IA), 4 of 20 reported sSMC cases were ICSI-induced pregnancies; 1 familial case and three de novo sSMC cases were described. Unfortunately, no data is provided in this study as to how many ICSI-induced pregnancies were studied at all. Thus, at present a more or less identical rate of sSMC presence in ICSI-induced compared to a normal newborn population is to be suggested.

The sSMC rate in newborns (Table IIA) of $0.044 \%$ was only almost half of the prenatally detected one (Table IA) and highlights that, in prenatal diagnostics, only a preselected human subpopulation was studied. Concluding, the rate of $0.075 \%$ of sSMC carriers in prenatal studies was biased by three main points which were already discussed by Blennow et al (28): a higher rate of cases with SSMC in prenatals compared to newborn can be due to i) the bias caused by the maternal age effect in prenatal series, ii) the fact that prenatal diagnosis is sometimes performed due to known or suspected fetal pathology, and/or iii) severely affected fetuses may result in miscarriages and will therefore not be included among newborn cases. Recently, proof for all three suggested effects plus a further effect (4) have been observed. (Ad 1) A maternal age effect, which was suggested for all chromosomes (16) was demonstrated at least for sSMC derived from chromosome 15 (29). (Ad 2 and 3) Prenatal diagnosis is performed also in a subset of fetuses which have suspect results in ultrasound and may result in miscarriages. This is the biological relevant subset which will not be seen in the newborn population. According to Kumar et al (30) $4.4 \%$ of sSMC pregnancies end in a stillbirth or spontaneous abortion. Also from the data summarized in Fig. 2 it is unlikely that this third effect takes place in a noteworthy proportion during the third trimester of pregnancy. If this would be the case in a significant rate, the percentage of de novo versus familial sSMC cases should decrease from early to later pregnancy. As shown in Fig. 2 this is not the case, with the rate remaining always more or less $\sim 2$ in cells of CVS, amniocytic fluid and newborn blood. (Ad 4) The last but numerically relevant 'bias' is the fact, that at present still $30-50 \%$ of pregnancies diagnosed with an sSMC fetus are terminated $(2,30,31)$, even though only $30 \%$ of sSMC cases manifest clinical symptoms (1). This means that a certain percentage of potentially healthy children with sSMC are aborted.

In conclusion, no data is available on the 'real rate' of sSMC carriers in the prenatal human general population. What is available is the clinically relevant frequency of $0.075 \%$ for the prenatally studied human population. Through this study for the first time sound and reliable values for the frequency of sSMC in prenatal, infertility and dysmorphism diagnostics are available and can be related to the sSMC rate in the normal control population.

\section{Acknowledgements}

This research was supported in part by the Dr Robert PflegerStiftung, Ernst-Abbe-Stiftung, the DFG (436 RUS 17/135/03; 436 RUS 17/109/04, 436 WER 17/1/04, 436 WER 17/5/05, 436 RUS 17/22/06, WE 3617/2-1), the DAAD, the EU (Marie Curie Fellowship HPMT-CT-200100273), the Schering Foundation and the Evangelische Studienwerk e.V. Villigst.

\section{References}

1. Liehr T, Claussen U and Starke H: Small supernumerary marker chromosomes (sSMC) in humans. Cytogenet Genome Res 107: $55-67,2004$

2. Warburton D: De novo balanced chromosome rearrangements and extra marker chromosomes identified at prenatal diagnosis: clinical significance and distribution of breakpoints. Am J Hum Genet 49: 995-1013, 1991.

3. Crolla JA: FISH and molecular studies of autosomal supernumerary marker chromosomes excluding those derived from chromosome 15: II. Review of the literature. Am J Med Genet 75: 367-381, 1998.

4. Graf MD, Christ L, Mascarello JT, Mowrey P, Pettenati M, Stetten G, Storto P, Surti U, Van Dyke DL, Vance GH, Wolff D and Schwartz S: Redefining the risks of prenatally ascertained supernumerary marker chromosomes: a collaborative study. J Med Genet 43: 660-664, 2006.

5. Paoloni-Giacobino A, Morris MA and Dahoun SP: Prenatal supernumerary $\mathrm{r}(16)$ chromosome characterized by multiprobe FISH with normal pregnancy outcome. Prenat Diagn 18: 751-752, 1998.

6. Liehr T, Mrasek K, Weise A, Dufke A, Rodriguez L, Martinez Guardia N, Sanchis A, Vermeesch JR, Ramel C, Polityko A, Haas OA, Anderson J, Claussen U, von Eggeling F and Starke H: Small supernumerary marker chromosomes progress towards a genotype-phenotype correlation. Cytogenet Genome Res 112: 23-34, 2006

7. Nietzel A, Rocchi M, Starke H, Heller A, Fiedler W, Wlodarska I, Loncarevic IF, Beensen V, Claussen U and Liehr T: A new multicolor-FISH approach for the characterization of marker chromosomes: centromere-specific multicolor-FISH (cenMFISH). Hum Genet 108: 199-204, 2001.

8. Starke H, Nietzel A, Weise A, Heller A, Mrasek K, Belitz B, Kelbova C, Volleth M, Albrecht B, Mitulla B, Trappe R, Bartels I, Adolph S, Dufke A, Singer S, Stumm M, Wegner RD, Seidel J, Schmidt A, Kuechler A, Schreyer I, Claussen U, von Eggeling F and Liehr T: Small supernumerary marker chromosomes (SMCs): genotype-phenotype correlation and classification. Hum Genet 114: 51-67, 2003.

9. Trifonov V, Seidel J, Starke H, Martina P, Beensen V, Ziegler M, Hartmann I, Heller A, Nietzel A, Claussen U and Liehr T: Enlarged chromosome 13 p-arm hiding a cryptic partial trisomy 6p22.2-pter. Prenat Diagn 23: 427-430, 2003. 
10. Liehr T, Starke H, Senger G, Melotte C, Weise A and Vermeesch JR: Overrepresentation of small supernumerary marker chromosomes (sSMC) from chromosome 6 origin in cases with multiple sSMC. Am J Med Genet A 140: 46-51, 2006.

11. Liehr T: (2006) sSMC homepage, http://mti-n.mti.unijena.de/ huwww/MOL_ZYTO/sSMC/00START.htm, 09/20/2006.

12. Martin RH, Mahadevan MM, Taylor PJ, Hildebrand K, Long-Simpson L, Peterson D, Yamamoto J and Fleetham J: Chromosomal analysis of unfertilized human oocytes. J Reprod Fertil 78: 673-678, 1986.

13. Eydoux P, Choiset A, Le Porrier N, Thepot F, Szpiro-Tapia S, Alliet J, Ramond S, Viel JF, Gautier E, Morichon N and Girard-Orgeolet S: Chromosomal prenatal diagnosis: study of 936 cases of intrauterine abnormalities after ultrasound assessment. Prenat Diagn 9: 255-269, 1989.

14. Lin CC, Gedeon MM, Griffith P, Smink WK, Newton DR, Wilkie L and Sewell LM: Chromosome analysis on 930 consecutive newborn children using quinacrine fluorescent banding technique. Hum Genet 31: 315-328, 1976.

15. Caron L, Tihy F and Dallaire L: Frequencies of chromosomal abnormalities at amniocentesis: over 20 years of cytogenetic analyses in one laboratory. Am J Med Genet 82: 149-154, 1999.

16. Hook EB and Cross PK: Extra structurally abnormal chromosomes (ESAC) detected at amniocentesis: frequency in approximately 75,000 prenatal cytogenetic diagnoses and associations with maternal and paternal age. Am J Hum Genet 40: 83-101, 1987.

17. Hook EB and Hamerton JL: The frequency of chromosome abnormalities detected in consecutive newborn studies differences between studies - results by sex and by severity of phenotypic involvement. In: Population Cytogenetics. Hook EB and Porter IH (eds). Academic Press Inc, New York, pp63-79, 1977.

18. Sachs ES, Van Hemel JO, Den Hollander JC and Jahoda MG: Marker chromosomes in a series of 10,000 prenatal diagnoses. Cytogenetic and follow-up studies. Prenat Diagn 7: 81-89, 1987 .

19. Brondum-Nielsen K and Mikkelsen M: A 10-year survey, 19801990 , of prenatally diagnosed small supernumerary marker chromosomes, identified by FISH analysis. Outcome and follow-up of 14 cases diagnosed in a series of 12,699 prenatal samples. Prenat Diagn 15: 615-619, 1995.

20. Hsu LY, Yu MT, Richkind KE, Van Dyke DL, Crandall BF Saxe DF, Khodr GS, Mennuti M, Stetten G, Miller WA and Priest JH: Incidence and significance of chromosome mosaicism involving an autosomal structural abnormality diagnosed prenatally through amniocentesis: a collaborative study. Prenat Diagn 16: 1-28, 1996.

21. Ferguson-Smith MA and Yates JR: Maternal age specific rates for chromosome aberrations and factors influencing them: report of a collaborative European study on 52,965 amniocenteses. Prenat Diagn 4: 5-44, 1984.

22. Nielsen $\mathbf{J}$ and Wohlert M: Chromosome abnormalities found among 34,910 newborn children: results from a 13-year incidence study in Arhus, Denmark. Hum Genet 87: 81-83, 1991.

23. Nielsen J and Rasmussen K: Extra marker chromosome in newborn children. Hereditas 81: 221-224, 1975

24. Mau-Holzmann UA: Somatic chromosomal abnormalities in infertile men and women. Cytogenet Genome Res 111: 317-336, 2005.

25. Liehr T: Familial small supernumerary marker chromosomes are predominantly inherited via the maternal line. Genet Med 8: 459-462, 2006.

26. Hume RF Jr, Kilmer-Ernst P, Wolfe HM, Ebrahim SA, Treadwell MC, Johnson MP and Evans MI: Prenatal cytogenetic abnormalities: correlations of structural rearrangements and ultrasonographically detected fetal anomalies. Am J Obstet Gynecol 173: 1334-1336, 1995.

27. Karaman B, Aytan M, Yilmaz K, Toksoy G, Onal EP, Ghanbari A, Engur A, Kayserili H, Yuksel-Apak M and Basaran S: The identification of small supernumerary marker chromosomes; the experiences of 15,792 fetal karyotyping from Turkey. Eur J Med Genet 49: 207-314, 2006.

28. Blennow E, Bui TH, Kristoffersson U, Vujic M, Anneren G, Holmberg E and Nordenskjold M: Swedish survey on extra structurally abnormal chromosomes in 39,105 consecutive prenatal diagnoses: prevalence and characterization by fluorescence in situ hybridization. Prenat Diagn 14: 1019-1028, 1994.
29. Crolla JA, Youings SA, Ennis S and Jacobs PA: Supernumerary marker chromosomes in man: parental origin, mosaicism and maternal age revisited. Eur J Hum Genet 13: 154-160, 2005.

30. Kumar C, Kleyman SM, Samonte RV and Verma RS: Marker chromosomes in fetal loss. Hum Reprod 12: 1321-1324, 1997.

31. Shaffer BL, Caughey AB, Cotter PD and Norton ME: Variation in the decision to terminate pregnancy in the setting of an abnormal karyotype with uncertain significance. Abstract book of the 54th annual meeting of the American Society of Human Genetics, p494 (abstract no. 2756), 2004.

32. Jotterand-Bellomo M, Pescia G, Nguyen The H, Gaide AC, Thonney F, Marguerat P, Pacaud F and Munier F: Cytogenetic analysis of 570 first trimester chorionic villi samplings: technique and results. Ann Genet 31: 14-20, 1988.

33. Fortuny A, Carrio A, Soler A, Cararach J, Fuster J and Salami C: Detection of balanced chromosome rearrangements in 445 couples with repeated abortion and cytogenetic prenatal testing in carriers. Fertil Steril 49: 774-779, 1988.

34. Crandall BF, Lebherz TB, Rubinstein L, Robertson RD, Sample WF, Sarti D and Howard J: Chromosome findings in 2,500 second trimester amniocenteses. Am J Med Genet 5: 345-356, 1980.

35. Hsieh FJ, Ko TM, Tseng LH, Chang LS, Pan MF, Chuang SM, Lee TY and Chen HY: Prenatal cytogenetic diagnosis in amniocentesis. J Formos Med Assoc 91: 276-282, 1992.

36. Boue J, Girard S, Thepot F, Choiset A and Boue A: Unexpected structural chromosome rearrangements in prenatal diagnosis. Prenat Diagn 2: 163-168, 1982

37. Yaegashi N, Senoo M, Uehara S, Suzuki H, Maeda T, Fujimori K, Hirahara $\mathrm{F}$ and Yajima A: Age-specific incidences of chromosome abnormalities at the second trimester amniocentesis for Japanese mothers aged 35 and older: collaborative study of 5484 cases. J Hum Genet 43: 85-90, 1998.

38. Park S, Lee BY, Kim YM, Kim JM, Lee MH, Kim JW, Cho EH, Park JY, Lee YH, Yang JH, Kim MY, Han JY and Ryu HM: De novo chromosomal aberrations in the fetus; genetic counseling and clinical outcome. J Korean Med Sci 18: 397-401, 2003.

39. Stengel-Rutkowski S and Nummermann C: (Prenatal diagnostics on chorion - German) Informationsblatt 6, Arbeitsgruppe der Abtlg. f. Pädiatrische Genetik und Pränatale Diagnostik d. Kinderpoliklinik d. Universität München, 1991.

40. Tabor A and Philip J: Incidence of fetal chromosome abnormalities in 2264 low-risk women. Prenat Diagn 7: 355-362, 1987.

41. Squire JA, Nauth L, Ridler MA, Sutton S and Timberlake C: Prenatal diagnosis and outcome of pregnancy in 2036 women investigated by amniocentesis. Hum Genet 61: 215-222, 1982.

42. Vejerslev LO and Mikkelsen M: The European collaborative study on mosaicism in chorionic villus sampling: data from 1986 to 1987. Prenat Diagn 9: 575-588, 1989.

43. Association of Clinical Cytogeneticists: Cytogenetic analysis of chorionic villi for prenatal diagnosis: an ACC collaborative study of U.K. data. Association of Clinical Cytogeneticists Working Party on Chorionic Villi in Prenatal Diagnosis. Prenat Diagn 14: 363-379, 1994.

44. Stengel-Rutkowski S, Brandmaier R, Ullrich H, Lehmann E and Murken J-D: Documentation and evaluation of prenatal diagnosis data in the federal republic of Germany [Schwerpunktprogramm der Deutschen Forschungsgemeinschaft (DFG) 'Pränatale Diagnostik genetisch bedingter Defekte']. In: Prenatal Diagnosis - Proceedings of the 3rd European Conference on Prenatal Diagnosis of Genetic Disorders. Murken J-D, StengelRutkowski S and Schwinger E (eds). Ferdinand Enke Publishers, Stuttgart, pp364-371, 1979.

45. Thein AT, Abdel-Fattah SA, Kyle PM and Soothill PW: An assessment of the use of interphase FISH with chromosome specific probes as an alternative to cytogenetics in prenatal diagnosis. Prenat Diagn 20: 275-280, 2000

46. Djalali M: The significance of accessory bisatellited marker chromosomes in amniotic fluid cell cultures. Ann Genet 33: 141-145, 1990.

47. Woo HY, Cho HJ, Kong SY, Kim HJ, Jeon HB, Kim EC, Park H, Kim YJ and Kim SH: Marker chromosomes in Korean patients: incidence, identification and diagnostic approach. J Korean Med Sci 18: 773-778, 2003.

48. Daniel A, Stewart L, Saville T, Brookwell R, Paull H, Purvis-Smith S and Lam-Po-Tang PR: Prenatal diagnosis in 3,000 women for chromosome, X-linked, and metabolic disorders. Am J Med Genet 11: 61-75, 1982. 
49. Grati FR, Grimi B, Frascoli G, Di Meco AM, Liuti R, Milani S, Trotta A, Dulcetti F, Grosso E, Miozzo M, Maggi F and Simoni G: Confirmation of mosaicism and uniparental disomy in amniocytes, after detection of mosaic chromosome abnormalities in chorionic villi. Eur J Hum Genet 14: 282-288, 2006.

50. Golbus MS, Loughman WD, Epstein CJ, Halbasch G, Stephens JD and Hall BD: Prenatal genetic diagnosis in 3000 amniocenteses. N Engl J Med 300: 157-163, 1979.

51. Al-Kouatly HB, Chasen ST, Gilbert F, Ahner R, Alonso LM and Chervenak FA: Correlation between rare chromosomal abnormalities and prenatal ultrasound findings. Am J Med Genet 107: 197-200, 2002.

52. Ledbetter DH, Zachary JM, Simpson JL, Golbus MS, Pergament E, Jackson L, Mahoney MJ, Desnick RJ, Schulman J, Copeland KL, Verlinsky Y, Yang-Feng T, Schonberg SA, Babu A, Tharapel A, Dorfmann A, Lubs HA, Rhoads GG, Fowler SE and de la Cruz F: Cytogenetic results from the U.S. Collaborative Study on CVS. Prenat Diagn 12: 317-345, 1992.

53. Bartsch O, Loitzsch A, Kozlowski P, Mazauric ML and Hickmann G: Forty-two supernumerary marker chromosomes (SMCs) in 43,273 prenatal samples: chromosomal distribution, clinical findings, and UPD studies. Eur J Hum Genet 13: 1192-1204, 2005.

54. Li MM, Howard-Peebles PN, Killos LD, Fallon L, Listgarten E and Stanley WS: Characterization and clinical implications of marker chromosomes identified at prenatal diagnosis. Prenat Diagn 20: 138-143, 2000.

55. Benn PA and Hsu LY: Incidence and significance of supernumerary marker chromosomes in prenatal diagnosis. Am J Hum Genet 36: 1092-1102, 1984.

56. Kaluzewski B, Helszer Z, Constantinou M, Burkholder SW, Coutinho WG, Skorski M, Corridori L, Anderson CE, Sherwood M, Debiec-Rychter M and Jackson LG: Extra structurally abnormal chromosomes (ESACs) - presentation of 10 new cases. Med Sci Monit 7: 427-434, 2001.

57. Lippman A, Tomkins DJ, Shime J and Hamerton JL: Canadian multicentre randomized clinical trial of chorion villus sampling and amniocentesis. Final report (incl. annexes). Prenat Diagn 12: 385-476, 1992.

58. Carrasco Juan JL, Otero Gomez A, Vilar Mesa MC, Garcia Miranda JL, Troyano Luque JM, Lopez Ramon y Cajal C and Parache Hernandez J: Small marker chromosomes in a series of 1,000 prenatal diagnoses by amniocentesis. Ann Genet 33: 40-42, 1990.

59. Dahoun-Hadorn S and Delozier-Blanchet C: Reflections on small supernumerary (marker) chromosomes: Could imprinting and isodisomy play a role in the phenotypic expression of hyperdiploidy? Ann Genet 33: 241-242, 1990.

60. van den Berg C, Van Opstal D, Brandenburg H, Wildschut HI, den Hollander NS, Pijpers L, Jan H, Galjaard R and Los FJ: Accuracy of abnormal karyotypes after the analysis of both short - and long-term culture of chorionic villi. Prenat Diagn 20: 956-969, 2000.

61. Wilson RD, Chitayat D and McGillivray BC: Fetal ultrasound abnormalities: correlation with fetal karyotype, autopsy findings, and postnatal outcome - five-year prospective study. Am J Med Genet 44: 586-590, 1992.

62. Palmer CG, Miles JH, Howard-Peebles PN, Magenis RE, Patil S and Friedman JM: Fetal karyotype following ascertainment of fetal anomalies by ultrasound. Prenat Diagn 7: 551-555, 1987.

63. van Zalen-Sprock MM, van Vugt JM, Karsdorp VH, Maas R and van Geijn HP: Ultrasound diagnosis of fetal abnormalities and cytogenetic evaluation. Prenat Diagn 11: 655-660, 1991.

64. Staebler M, Donner C, Van Regemorter N, Duprez L, De Maertelaer V, Devreker F and Avni F: Should determination of the karyotype be systematic for all malformations detected by obstetrical ultrasound? Prenat Diagn 25: 567-573, 2005.

65. Daniel A, Athayde N, Ogle R, George AM, Michael J, Pertile MD, Bryan J, Jammu V and Trudinger BJ: Prospective ranking of the sonographic markers for aneuploidy: data of 2143 prenatal cytogenetic diagnoses referred for abnormalities on ultrasound. Aust NZ J Obstet Gynaecol 43: 16-26, 2003.

66. Rizzo N, Pittalis MC, Pilu G, Orsini LF, Perolo A and Bovicelli L: Prenatal karyotyping in malformed fetuses. Prenat Diagn 10: 17-23, 1990.

67. Hentemann M, Rauskolb R, Ulbrich R and Bartels I: Abnormal pregnancy sonogram and chromosomal anomalies: four years' experience with rapid karyotyping. Prenat Diagn 9: 605-612, 1989.
68. Lam R, Ma S, Robinson WP, Chan T and Yuen BH: Cytogenetic investigation of fetuses and infants conceived through intracytoplasmic sperm injection. Fertil Steril 76: 1272-1275, 2001.

69. Van Golde R, Boada M, Veiga A, Evers J, Geraedts J and Barri P: A retrospective follow-up study on intracytoplasmic sperm injection. J Assist Reprod Genet 16: 227-232, 1999.

70. Causio F, Fischetto R, Schonauer LM and Leonetti T: Intracytoplasmic sperm injection in infertile patients with structural cytogenetic abnormalities. J Reprod Med 44: 859-864, 1999.

71. Van Opstal D, Los FJ, Ramlakhan S, Van Hemel JO, Van Den Ouweland AM, Brandenburg H, Pieters MH, Verhoeff A, Vermeer MC, Dhont M and In't Veld PA: Determination of the parent of origin in nine cases of prenatally detected chromosome aberrations found after intracytoplasmic sperm injection. Hum Reprod 12: 682-686, 1997.

72. Testart J, Gautier E, Brami C, Rolet F, Sedbon E and Thebault A: Intracytoplasmic sperm injection in infertile patients with structural chromosome abnormalities. Hum Reprod 11: 2609-2612, 1996.

73. Samli H, Solak M, Imirzalioglu N, Beyatli Y, Simsek S and Kahraman S: Fetal chromosomal analysis of pregnancies following intracytoplasmic sperm injection with amniotic tissue culture. Prenat Diagn 23: 847-850, 2003.

74. Szigeti Z, Toth-Pal E, Papp C, Beke A, Joo J, Ban Z, Mezei G and Papp Z: Cytogenetic investigation of fetuses conceived by intracytoplasmatic sperm injection. Prenat Diagn 24: 579-580, 2004.

75. Wennerholm UB, Bergh C, Hamberger L, Lundin K, Nilsson L, Wikland $M$ and Kallen B: Incidence of congenital malformations in children born after ICSI. Hum Reprod 15: 944-948, 2000.

76. Loft A, Petersen K, Erb K, Mikkelsen AL, Grinsted J, Hald F, Hindkjaer J, Nielsen KM, Lundstrom P, Gabrielsen A, Lenz S, Hornnes P, Ziebe S, Ejdrup HB, Lindhard A, Zhou Y and Nyboe Andersen A: A Danish national cohort of 730 infants born after intracytoplasmic sperm injection (ICSI) 1994-1997. Hum Reprod 14: 2143-2148, 1999.

77. Jozwiak EA, Ulug U, Mesut A, Erden HF and Bahceci M: Prenatal karyotypes of fetuses conceived by intracytoplasmic sperm injection. Fertil Steril 82: 628-633, 2004.

78. Bonduelle M, Van Assche E, Joris H, Keymolen K, Devroey P, Van Steirteghem A and Liebaers I: Prenatal testing in ICSI pregnancies: incidence of chromosomal anomalies in 1586 karyotypes and relation to sperm parameters. Hum Reprod 17: 2600-2614, 2002

79. Wisanto A, Bonduelle M, Camus M, Tournaye H, Magnus M, Liebaers I, Van Steirteghem A and Devroey P: Obstetric outcome of 904 pregnancies after intracytoplasmic sperm injection. Hum Reprod 11 (suppl 4): 121-130, 1996.

80. Aboulghar H, Aboulghar M, Mansour R, Serour G, Amin Y and Al-Inany H: A prospective controlled study of karyotyping for 430 consecutive babies conceived through intracytoplasmic sperm injection. Fertil Steril 76: 249-253, 2001

81. Xia JH, Li LY, Dai HP, Hu SQ, He XX, Xu FM, Xu J, Xiao GH, Hu XD and Lu HL: Karyotype analysis in 2,079 consecutive liveborn infants. Chin Med J 95: 687-691, 1982.

82. Maeda T, Ohno M, Matsunobu A, Yoshihara K and Yabe N: A cytogenetic survey of 14,835 consecutive liveborns. Jinrui Idengaku Zasshi 36: 117-129 1991.

83. Buckton KE, Spowart G, Newton MS and Evans HJ: Forty four probands with an additional 'marker' chromosome. Hum Genet 69: 353-370, 1985.

84. Bratkowska W, Hubner H, Ferenc T, Szpakowski M, Krajewski J and Budzko W: Chromosome studies in 3665 consecutive newborn children. Acta Anthropogenet 9: 153-161, 1985.

85. Buchkov NP, Kuleshov NP, Chebotarev AN, Alekhin VI and Midian SA: Population cytogenetic investigation of newborn in Moscow. Humangenetik 22: 139-152, 1974.

86. Hansteen IL, Varslot K, Steen-Johnsen J and Langard S Cytogenetic screening of a new-born population. Clin Genet 21 309-314, 1982.

87. Tawn EJ and Earl R: The frequencies of constitutional chromosome abnormalities in an apparently normal adult population. Mutat Res 283: 69-73, 1992.

88. Cora T, Demirel S and Acar A: Chromosomal abnormalities in mentally retarded children in the Konya region - Turkey. Genet Couns 11: 53-55, 2000.

89. Kodama Y: Cytogenetic and dermatoglyphic studies on severely handicapped patients in an institution. Acta Med Okayama 36: 383-397, 1982 . 
90. Srsen S, Misovicova N, Srsnova K and Volna J: Chromosome aberrations in a group of mentally retarded persons. Cesk Psychiatr 85: 9-16, 1989.

91. Al Husain M and Zaki OK: A survey of 1,000 cases referred for cytogenetic study to King Khalid University Hospital, Saudi Arabia. Hum Hered 49: 208-214, 1999.

92. Higurashi M, Iijima S, Takeshita T, Oda M, Takadaya K and Watanabe $\mathrm{N}$ : Incidence of malformation syndromes and chromosomal abnormalities in 22,063 newborn infants in Tokyo. Jinrui Idengaku Zasshi 30: 1-8, 1985.

93. Fryns JP, Kleczkowska A and Van den Berghe H: Small accessory chromosomes (SAC) and their genotype - phenotype correlation. J Genet Hum 30: 215-232, 1982.

94. Rasmussen K, Nielsen J and Dahl G: The prevalence of chromosome abnormalities among mentally retarded persons in a geographically delimited area of Denmark. Clin Genet 22: 244-255, 1982

95. Hernández A, Reynoso MC, Soto F, Quinones D, Nazara Z, Rolon A, Jimenez ME and Blancarte R: Aneuploidies, chromosome aberrations and dominant gene mutations detected in 113,913 consecutive newborn children in Mexico. Mutat Res 232: 23-29, 1990.

96. Moreno-Garcia M, Fernandez-Martinez FJ and Barreiro Miranda E: Chromosomal anomalies in patients with short stature. Pediatr Int 47: 546-549, 2005

97. Wuu KD, Wuu SW and Liu IW: A cytogenetic survey of mentally retarded children in Taiwan: final report on the incidence of chromosome abnormalities. Proc Natl Sci Counc Repub China B 8: 83-88, 1984.

98. Phelan MC, Crawford EC and Bealer D: Mental retardation in South Carolina III. chromosome aberrations. Proc Greenwood Genet Center 15: 45-60, 1996.

99. Price WH, Brunton M, Buckton $K$ and Jacobs PA: Chromosome survey of new patients admitted to the four maximum security hospitals in the United Kingdom. Clin Genet 9: 389-398, 1976.

100. Bourgeois M and Benezech M: Cytogenic survey of 600 mentally retarded hospitalized patients. Encephale 3: 189-202, 1977.

101.Hou JW and Wang TR: Unusual features in children with inv dup(15) supernumerary marker: a study of genotype-phenotype correlation in Taiwan. Eur J Pediatr 157: 122-127, 1998.

102.Hong KE, Kim JH, Moon SY and Oh SK: Chromosomal abnormalities in child psychiatric patients. J Korean Med Sci 14: 377-385, 1999

103. Kim SS, Jung SC, Kim HJ, Moon HR and Lee JS: Chromosome abnormalities in a referred population for suspected chromosomal aberrations: a report of 4117 cases. J Korean Med Sci 14: 373-376, 1999

104. Singh DN, Osborne RA, Paul JR, Catoe S, Katzberg A, Hennigar GR and Barnett CD: Cytogenetic survey of 504 mentally retarded individuals. J Ment Defic Res 18: 293-305, 1974.

105.Kirkilionis AJ and Sergovich FR: Supernumerary marker chromosomes in a mentally retarded population identified as inv dup(15). Clin Genet 31: 425-428, 1987.

106. Toyota T, Shimizu H, Yamada K, Yoshitsugu K, Meerabux J, Hattori E, Ichimiya T and Yoshikawa T: Karyotype analysis of 161 unrelated schizophrenics: no increased rates of $\mathrm{X}$ chromosome mosaicism or inv(9), using ethnically matched and age-stratified controls. Schizophr Res 52: 171-179, 2001 .

107. Mulcahy MT and Jenkyn J: Results of 538 chromosome studies on patients referred for cytogenetic analysis. Med J Aust 2: 1333-1338, 1972.

108. Battaglia A, Bianchini E and Carey JC: Diagnostic yield of the comprehensive assessment of developmental delay/mental retardation in an institute of child neuropsychiatry. Am J Med Genet 82: 60-66, 1999.

109. Felix TM, Leite JC, Maluf SW and Coelho JC: A genetic diagnostic survey in a population of 202 mentally retarded institutionalized patients in the south of Brazil. Clin Genet 54: 219-223, 1998

110. Borgaonkar S, Schimke RN and Thomas H: Report of five unrelated patients with a small, metacentric, extra chromosome or fragment. J Genet Hum 19: 207-222, 1971

111. Baschat AA, Kupker W, al Hasani S, Diedrich K and Schwinger E: Results of cytogenetic analysis in men with severe subfertility prior to intracytoplasmic sperm injection. Hum Reprod 11: 330-333, 1996.
112. Kleiman SE, Yogev L, Gamzu R, Hauser R, Botchan A, Lessing JB, Paz G and Yavetz H: Genetic evaluation of infertile men. Hum Reprod 14: 33-38, 1999.

113.Penna Videaú S, Araujo H, Ballesta F, Ballesca JL and Vanrell JA: Chromosomal abnormalities and polymorphisms in infertile men. Arch Androl 46: 205-210, 2001.

114. Quilter CR, Svennevik EC, Serhal P, Ralph D, Bahadur G, Stanhope R, Sutterlin M, Delhanty JD and Taylor KE: Cytogenetic and Y chromosome microdeletion screening of a random group of infertile males. Fertil Steril 79: 301-307, 2003.

115. Stuppia L, Gatta V, Calabrese G, Guanciali Franchi P, Morizio E, Bombieri C, Mingarelli R, Sforza V, Frajese G, Tenaglia R and Palka G: A quarter of men with idiopathic oligo-azoospermia display chromosomal abnormalities and microdeletions of different types in interval 6 of Yq11. Hum Genet 102: 566-570, 1998.

116. Raziel A, Friedler S, Schachter M, Kasterstein E, Strassburger D and Ron-El R: Increased frequency of female partner chromosomal abnormalities in patients with high-order implantation failure after in vitro fertilization. Fertil Steril 78: 515-519, 2002

117. Westlander G, Hamberger L, Hanson C, Lundin K, Nilsson L, Soderlund B, Werner C and Bergh C: Diagnostic epididymal and testicular sperm recovery and genetic aspects in azoospermic men. Hum Reprod 14: 118-122, 1999.

118. Lange R, Johannson G and Engel W: Chromosome studies in in-vitro fertilization patients. Hum Reprod 8: 572-574, 1993.

119. Schreurs A, Legius E, Meuleman C, Fryns JP and D'Hooghe TM: Increased frequency of chromosomal abnormalities in female partners of couples undergoing in vitro fertilization or intracytoplasmic sperm injection. Fertil Steril 74: 94-96, 2000

120. Pauer HU, Hinney B, Michelmann HW, Krasemann EW, Zoll B and Engel W: Relevance of genetic counselling in couples prior to intracytoplasmic sperm injection. Hum Reprod 12: 1909-1912, 1997.

121. Farzanfar F and Azimi C: Cytogenetic analysis in 257 infertile males in Iran. Chromosome Res 13 (suppl 1): 36 (abstract no. 1.103-P), 2005

122. Crüger DG, Agerholm I, Byriel L, Fedder J and Bruun-Petersen G: Genetic analysis of males from intracytoplasmic sperm injection couples. Clin Genet 64: 198-203, 2003.

123. Micic M, Micic S and Diklic V: Chromosomal constitution of infertile men. Clin Genet 25: 33-36, 1984.

124. Matsuda T, Nonomura M, Okada K, Hayashi K and Yoshida O Cytogenetic survey of subfertile males in Japan. Urol Int 44: 194-197, 1989.

125. Haidl G, Peschka B, Schwanitz G, Montag M, van der Ven K and van der Ven H: Cytogenetic and andrological status and ICSI-results in couples with severe male factor infertility. Asian J Androl 2: 293-296, 2000.

126. Yoshida A, Miura K and Shirai M: Cytogenetic survey of 1,007 infertile males. Urol Int 58: 166-176, 1997.

127. Makino T, Tabuchi T, Nakada K, Iwasaki K, Tamura S and Iizuka R: Chromosomal analysis in Japanese couples with repeated spontaneous abortions. Int J Fertil 35: 266-270, 1990.

128. Celep F, Karaguzel A, Ozeren M and Bozkaya H: The frequency of chromosomal abnormalities in patients with reproductive failure. Eur J Obstet Gynecol Reprod Biol 127: 106-109, 2006

129. Palka G, Guanciali-Franchi P, Clementini E, Tiboni GM, Palka C, Iezzi I, Di Tecco A, Morizio E, Fantasia D, Marino M, Stuppia L, Calabrese G and Dallapiccola B: Chromosomal abnormalities in 2078 infertile couples referred for assisted reproductive techniques (ART). Abstract book of the 54th annual meeting of the American Society of Human Genetics, p142 (abstract no. 686), 2004

130. Peschka B, Leygraaf J, van der Ven K, Montag M, Schartmann B, Schubert R, van der Ven H and Schwanitz G: Type and frequency of chromosome aberrations in 781 couples undergoing intracytoplasmic sperm injection. Hum Reprod 14: 2257-2263, 1999

131. Radojcic Badovinac A, Buretic-Tomljanovic A, Starcevic N, Kapovic M, Vlastelic I and Randic L: Chromosome studies in patients with defective reproductive success. Am J Reprod Immunol 44: 279-283, 2000 .

132. Gekas J, Thepot F, Turleau C, Siffroi JP, Dadoune JP, Briault S, Rio M, Bourouillou G, Carre-Pigeon F, Wasels R, Benzacken B and Association des Cytogeneticiens de Langue Francaise: Chromosomal factors of infertility in candidate couples for ICSI: an equal risk of constitutional aberrations in women and men. Hum Reprod 16: 82-90, 2001. 
133. Hens L, Bonduelle M, Liebaers I, Devroey P and Van Steirteghem AC: Chromosome aberrations in 500 couples referred for in-vitro fertilization or related fertility treatment. Hum Reprod 3: 451-457, 1988.

134. Meschede D, Lemcke B, Exeler JR, De Geyter C, Behre HM, Nieschlag E and Horst J: Chromosome abnormalities in 447 couples undergoing intracytoplasmic sperm injection prevalence, types, sex distribution and reproductive relevance. Hum Reprod 13: 576-582, 1998.

135. Scholtes MC, Behrend C, Dietzel-Dahmen J, van Hoogstraten DG, Marx K, Wohlers S, Verhoeven $\mathrm{H}$ and Zeilmaker GH: Chromosomal aberrations in couples undergoing intracytoplasmic sperm injection: influence on implantation and ongoing pregnancy rates. Fertil Steril 70: 933-937, 1998.

136. Morel F, Douet-Guilbert N, Le Bris MJ, Amice V, Le Martelot MT, Roche S, Valeri A, Derrien V, Amice J and De Braekeleer M: Chromosomal abnormalities in couples undergoing intracytoplasmic sperm injection. A study of 370 couples and review of the literature. Int J Androl 27: 178-182, 2004.

137. Van Assche E, Bonduelle M, Tournaye H, Joris H, Verheyen G, Devroey P, Van Steirteghem A and Liebaers I: Cytogenetics of infertile men. Hum Reprod 11 (suppl 4): 1-24, 1996.

138. Tuerlings JH, de France HF, Hamers A, Hordijk R, Van Hemel JO, Hansson K, Hoovers JM, Madan K, Van der Blij-Philipsen M, Gerssen-Schoorl KB, Kremer JA and Smeets DF: Chromosome studies in 1792 males prior to intra-cytoplasmic sperm injection: the Dutch experience. Eur J Hum Genet 6: 194-200, 1998.
139. Chandley AC, Edmond P, Christie S, Gowans L, Fletcher J, Frackiewicz A and Newton M: Cytogenetics and infertility in man. I. Karyotype and seminal analysis: results of a five-year survey of men attending a subfertility clinic. Ann Hum Genet 39: 231-254, 1975 .

140. Pandiyan N and Jequier AM: Mitotic chromosomal anomalies among 1210 infertile men. Hum Reprod 11: 2604-2608, 1996.

141. Mau UA, Bäckert IT, Kaiser P and Kiesel L: Chromosomal findings in 150 couples referred for genetic counselling prior to intracytoplasmic sperm injection. Hum Reprod 12: 930-937, 1997.

142. Bourrouillou G, Dastugue N and Colombies P: Chromosome studies in 952 infertile males with a sperm count below 10 million/ml. Hum Genet 71: 366-367, 1985.

143. Dohle GR, Halley DJ, van Hemel JO, van den Ouwel AM, Pieters MH, Weber RF and Govaerts LC: Genetic risk factors in infertile men with severe oligozoospermia and azoospermia. Hum Reprod 17: 13-16, 2002.

144. Retief AE, Van Zyl JA, Menkveld R, Fox MF, Kotze GM and Brusnicky J: Chromosome studies in 496 infertile males with a sperm count below 10 million/ml. Hum Genet 66: 162-164, 1984.

145. Nagvenkar P, Desai K, Hinduja I and Zaveri K: Chromosomal studies in infertile men with oligozoospermia \& nonobstructive azoospermia. Indian J Med Res 122: 34-42, 2005. 